\title{
Alternative Invitro Propagation: Use of Sugarcane Bagasse as a Low Cost Support Material During Rooting Stage of Strawberry Cv. Dover
}

\author{
Radjiskumar Mohan ${ }^{1}$, Eduardo Assami Chui ${ }^{1}$, Luis Antonio Biasi ${ }^{2}$ and Carlos Ricardo \\ Soccol $^{1 *}$ \\ ${ }^{1}$ Laboratório de Processos Biotecnológicos; Departamento de Engenharia Química; Universidade Federal do \\ Paraná; Centro Politécnico; soccol@ufpr.br Curitiba - PR - Brasil. ${ }^{2}$ Departamento de Agronomia; Universidade \\ Federal do Paraná; Laboratório de Fitotecnia e Fitossanitarismo; Curitiba - PR - Brasil
}

\begin{abstract}
The purpose of this work was to reduce the cost and improve the quality of the plant material during the micropropagation process in tissue culture. Partially improvement in the rooting process, coupled with cost reduction was obtained during the invitro rooting by the use of a natural support based on sugarcane bagasse as a substitute for the traditionally used agar gelled medium. The tests were conducted with micro-cuttings of strawberry cv. Dover using a medium composed of half strength MS medium (1962), 3\% sucrose and 0.05 BAP mg. $l^{-1}$. The roots number, shoots number, length, and the height of aerial part of 8 independent plants were recorded after 10, 20, 30, and 40 days of culture. Also, an acclimatization tests were realized of the rooted shoots from both the media. A comparison with agar-grown micro-cuttings showed that the sugarcane bagasse yielded better results (14, 40, 15 and 12 respectively). Acclimatization tests were $83 \%$ from the agar gelled medium against 100\% from the bagasse medium. As the Paraná State, Brazil, possess in great number of the sugarcane bagasse; this can feed the alternative technology invented on the area of micropropagation techniques
\end{abstract}

Key wors: Invitro rooting, alternative support, strawberry

\section{INTRODUCTION}

Since a long time Brazil is the largest world producer of sugarcane and Paraná one of its main producing states (www.ibge.com.br). During the processing to extract the juice 27 to $30 \%$ of residues are generated. Attempts have been made to use these residues for value-addition. One of such biotechnological application was on using sugarcane bagasse as a support material in rooting process of apple rootstocks in micropropagation technology (MOHAN et al., 2001, 2004).
Micropropagation of strawberry plants was introduced in 1974 (BOXUS). Immediately, the most important European nurseries producing several millions plants per year, were interested in this technique. The two basic reasons that gave the importance to this technique were: it gave a definitive answer to the problems of soil fungi, causing a lot of damage to the strawberry fields and by another way, tissue culture plants seemed to produce more runners per mother plant in a short time. Plant organisms and tissues are most suitably retained above the surface of a culture medium by using some kind of gelling agent or by

\footnotetext{
Author for correspondence
} 
some mechanical support. Agar is widely used as gelling agent for tissue culture media (GEORGE, 1993). Several suitable products are now available for gelling plant media, but the results obtained in each may differ considerably. The selection of the most suitable material, in terms of quality, rate and costs of propagation has become another task in building up a suitable protocol for the tissue culture propagation of any particular plant (GEORGE, 1993). Aeration of tissues and of roots, when grown on a porous substrate, is better than it would be in agar or static liquids (GEORGE, 1993). When mechanical supports (porous materials) are used, it must be not only autoclavable, but also inert, must not contain toxic compounds, must not be digested by the plant enzymes and might not react strongly with the media contents. The objective of this work was to develop a extremely simple and cheap invitro rooting technique for strawberry cv. Dover by using agro-industrial residues as an alternative support system.

\section{MATERIALS AND METHODS}

Invitro established shoots of strawberry cv. Dover were obtained from our laboratory. They were previously subcultured four times. Five to six shoots (1-2 cm long) were used per culture flask. Every culture flask contained $40 \mathrm{ml}$ of MS culture medium (Murashige and Skoog, 1962) supplemented with $4.4 \mu \mathrm{M}$ 6-benzylaminopurine (BAP). This medium was used for the multiplication of the plant material. The medium was sterilized at $121^{\circ} \mathrm{C}$ for 20 minutes. The $\mathrm{pH}$ was adjusted to 5.8 before autoclaving. The material was subcultured five times until enough material was obtained. Cultures were maintained at $26 \pm 2^{\circ} \mathrm{C}$ under a $16 \mathrm{~h}$ photoperiod (photon flux of $40 \mu \mathrm{mol} \mathrm{m} \mathrm{m}^{-2} \mathrm{~s}^{-1}$, white fluorescent tubes). Sugarcane bagasse was collected from three sugarcane juice sellers. Only the internal part (medular parenchyma) of the bagasse was used. It was washed two times with tab water, in order to take out the sugars and other impurities and one more time with de-ionized water to eliminate the soluble salts and impurities. The washed bagasse was dried in trays for $24 \mathrm{~h}$ at $90 \mathrm{oC}$ in an air oven. The dry bagasse was cut in small parts of $1 \mathrm{~cm}$ with a knife mill and was refined to smaller or fine parts in an industrial blender $(0.84-0.18 \mathrm{~mm})$. The refined or crushed bagasse was classified with a tray sieve in particle size of $0.84 \mathrm{~mm}$, between 0.84 and $0.18 \mathrm{~mm}$ and below $0.18 \mathrm{~mm}$. The classified material was stored separately in a dry room until use. In every culture flask containing $3 \mathrm{~g}$ of the sugarcane bagasse (particle size $<0.18$ $\mathrm{mm})$ and $35 \mathrm{ml}$ of the liquid medium was added (half strength MS $+0.05 \mathrm{mg} . \mathrm{l}^{-1} \mathrm{IBA}$ ). The control consisted of culture flasks containing solid culture medium, half force $(1 / 2 \mathrm{MS})$ supplemented with 0.05 mg. $l^{-1}$ BAP and 6g. $l^{-1}$ Plant Agar (Duchefa ${ }^{\circledR}$ ). Each flask contained five shoots with a aproximated length of $2.0 \mathrm{~cm}$. Ten culture flasks were used for every treatment. After 10, 20, 30 and 40 days, eight shoots were taken out randomly from the flasks containing bagasse and agar-gelled medium. The experiment was repeated three times. The following factors were recorded: number of roots per shoot, root length, shoots length and percentage of rooting. An acclimatization test was also carried out with the rooted explants. The color and appearance of the plants and extent of hyperhydricity were also evaluated. Also, a time and cost Analyze were realized. Data were analyzed using the MSTAT program, and ANOVA and Tukey's tests were applied.

\section{RESULTS AND DISCUSSION}

The results of the comparison tests about the quantity of formed roots between the media with the bagasse (alternative support) and the normal medium (commercial) are presented in Fig. 1.

Fig. 1 showed that the medium with sugarcane bagasse provided a better performance over the number of roots formed. Apparently the diffusion of BAP through the bagasse medium flowed more easily than in the medium with agar, thus providing a better root induction, where this phenomena must be limited in the agar medium as mentioned related by ROMBERGER and TABOR (1971) and DEBERGH (1981).

It was also observed that the difference between the two media used started with $6.12 \%$ in 10 days and reached to $14.04 \%$ at the end of 40 days of cultivation. Once determined the capacity of root formation, induction and organization, the elongation phase started. Fig. 2 shows the comparison of root lengths between the two different media used. 


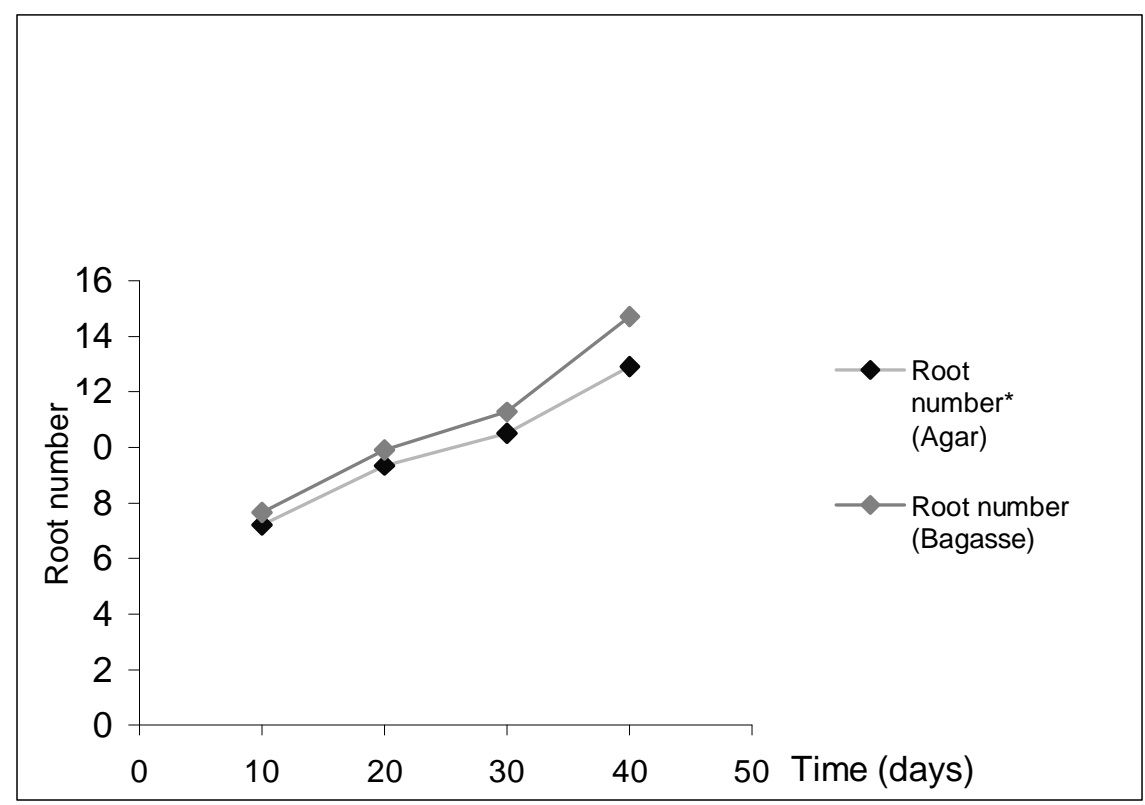

Figure 1 - Comparative results of number of formed roots in the two different support media used, sugarcane bagasse and agar (particle size <0.18). *Mean of 8 shoots.

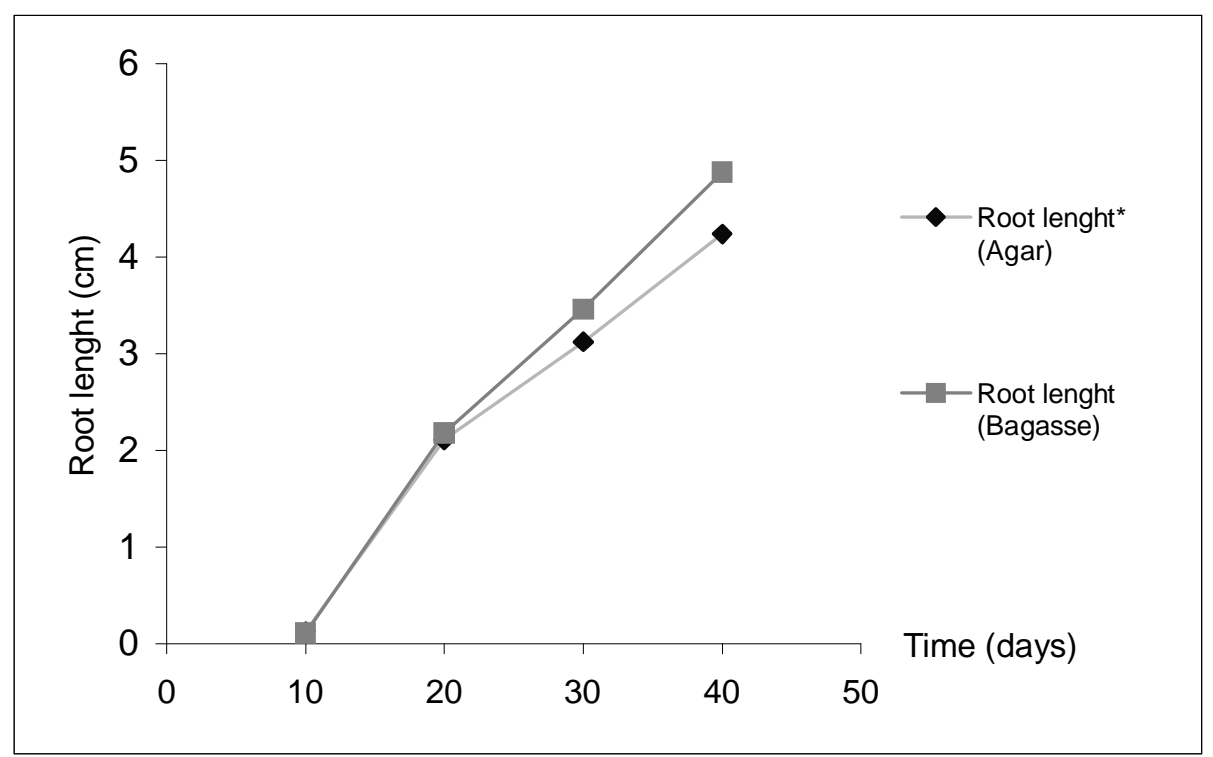

Figure 2 - Comparative results of root lengths in the two different support media used, sugarcane bagasse and agar (particle size <0.18). * Mean of 8 shoots.

It was observed that the roots practically grew in the same form during the first 10 days in both media. The retarded growth of the roots could be influenced by the presence of traces of phenolic compounds, present in the sugarcane bagasse. Some of these parts must be entered with the selected material (medular parenchyma) when the selection technique is not performed in the right way. Thus, it was yet not possible at the moment of the selection to have a very good separation of the lignin from the other parts. This is a very important point, since these compounds 
are toxic, retardant and growth inhibitor agents (GEORGE, 1993). However, after 40 days of cultivation, this was $15.03 \%$ in favor of the bagasse medium. Fig. 3 shows this differences (white arrows).
Fig. 4 showed that the alternative support medium was more efficient in the shoots height. After 40 days of cultivation, the height of the shoots reached at $4.40 \mathrm{~cm}$ against $4.02 \mathrm{~cm}$ of the commercial medium with $12 \%$ of difference (Fig. 5.).

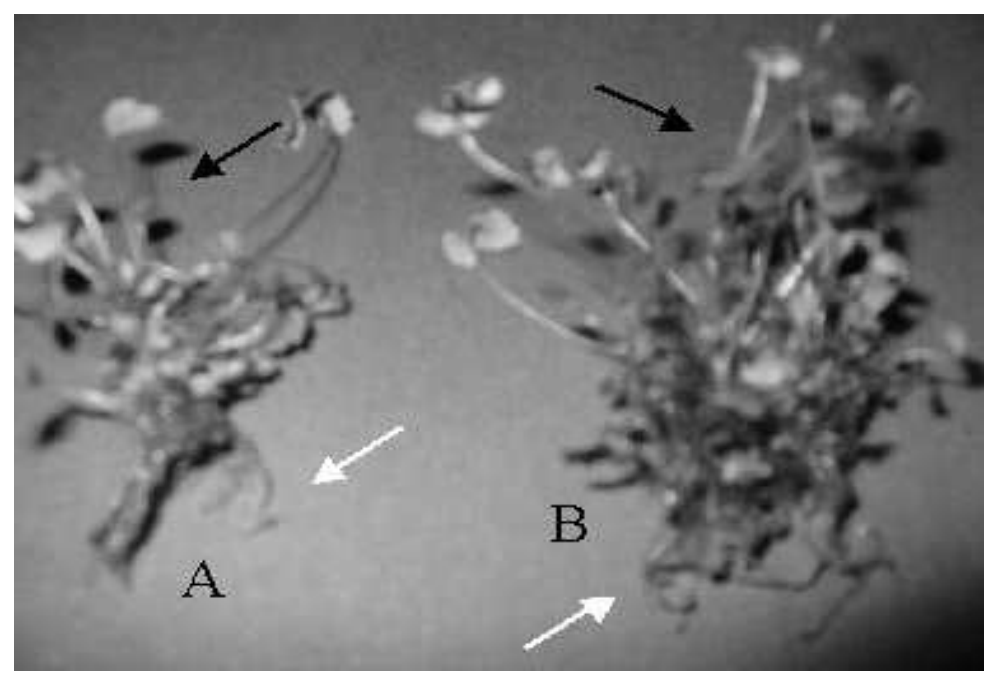

Figure 3 - Root formation (white arrows) and number of shoots demonstrated (black arrows) after 40 days of cultivation: A - Agar; B - Sugarcane bagasse

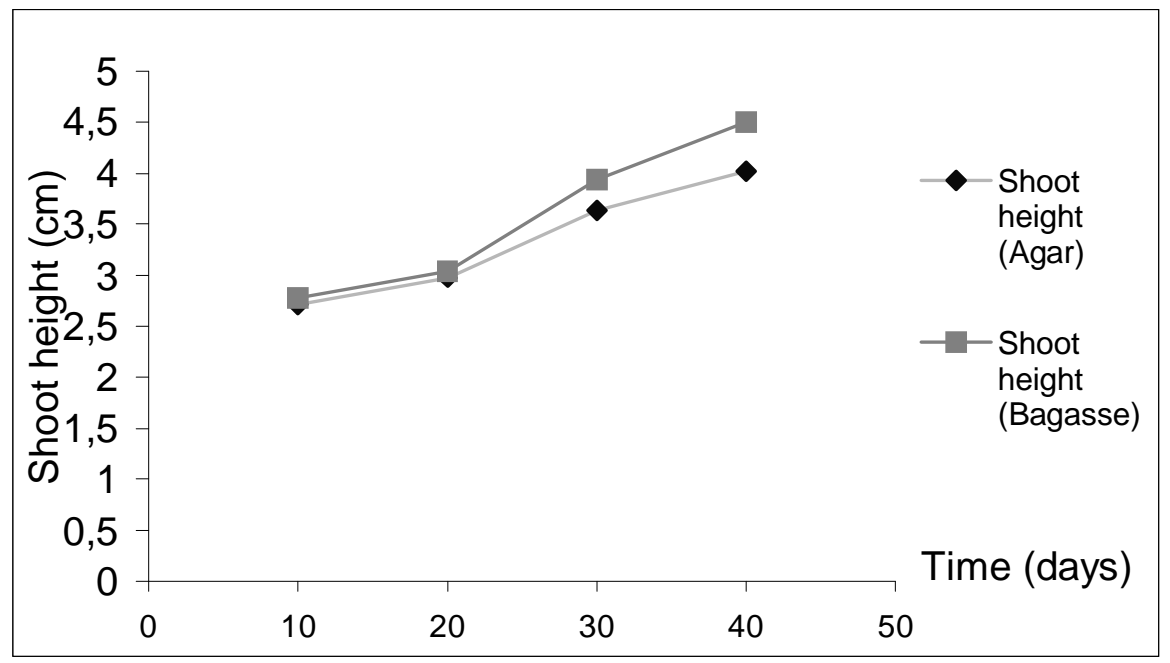

Figure 4 - Comparative results of shoots height in the two different support media used, sugarcane bagasse and agar (particle size $<0.18$ ). *Mean of 8 shoots. 


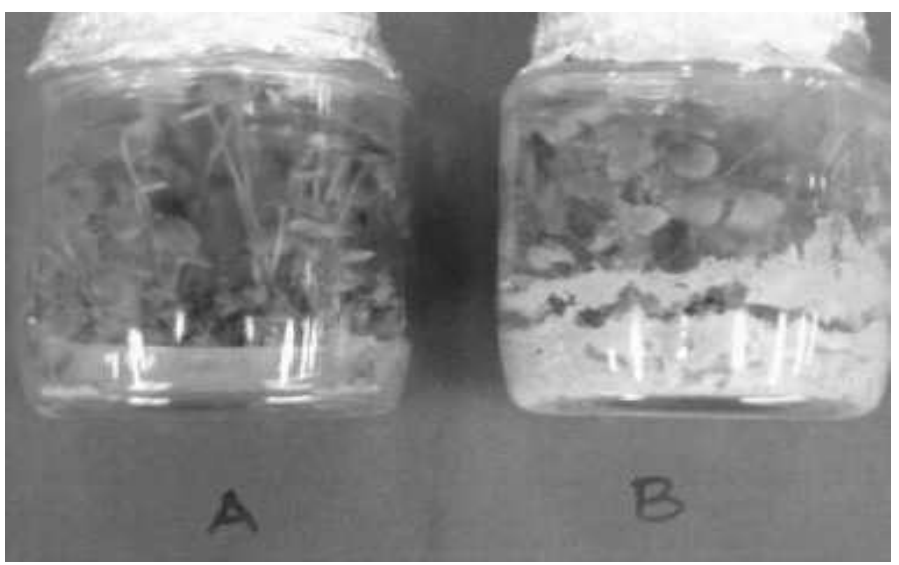

Figure 5 - Shoot height after 40 days of cultivation: A - Agar; B - Sugarcane bagasse

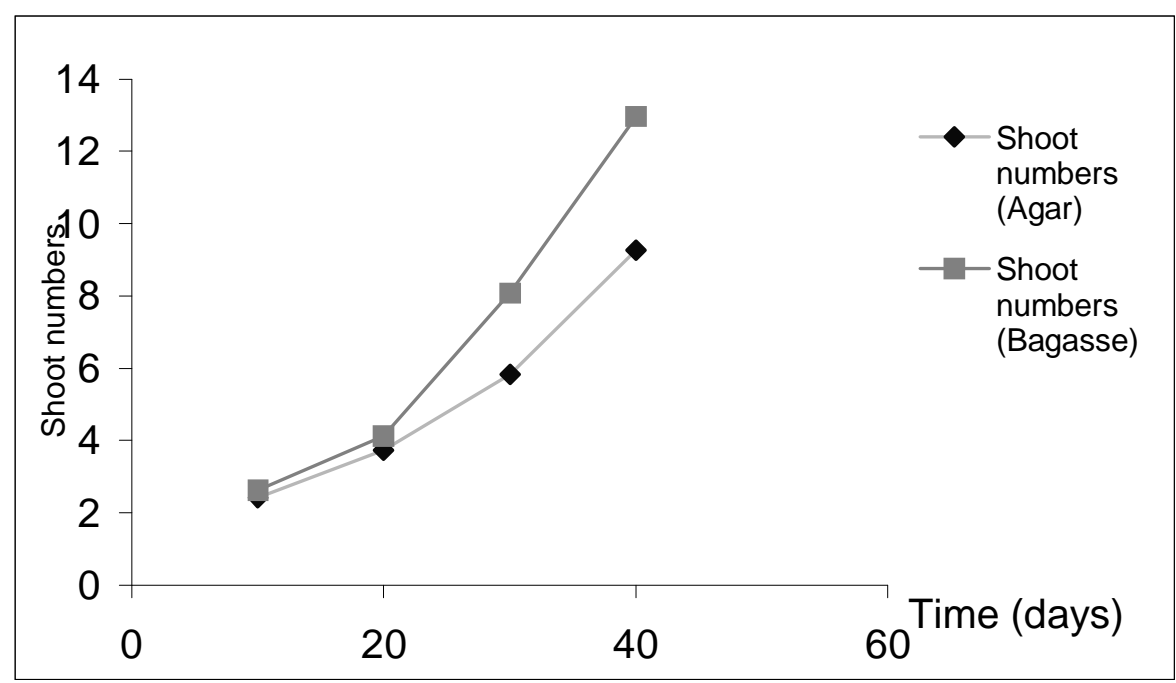

Figure 6 - Comparative results of number of shoots per explant in the two different support media used, sugarcane bagasse and agar (particle size < 0.18). * Mean of 8 shoots \pm standard deviation

Apparently the diffusion of the nutrients in to the bagasse medium was more efficient, thus inducing a better metabolic activity, giving a better stem growth. Also the aeration into the bagasse support (porous) should be higher (GEORGE, 1993) which is essential for plant growth. Fig. 6 showed that the shoots per explant in the bagasse medium grew significantly better than in the agar medium. The difference started with $8.64 \%$ at $10^{\text {th }}$ day of cultivation and went up to $40.02 \%$ after 40 days.

The growth after 40 days can be seen in the Fig. 3 (black arrows), which demonstrated that the medium with bagasse had better performance upside the agar medium. The percentage of survived plants of strawberry cv. Dover, during first two weeks from the two media, the agar (commercial) and the bagasse (alternative) were 83 and 100, respectively. It was also observed that the plants in the acclimatization process rooted in the bagasse medium were adapting and growing faster than from the agar medium (data not presented). 


\section{CONCLUSIONS}

In these work, an evaluation of the possibilities for the use of sugarcane bagasse as a substitute for agar in the rooting medium of shoots in plant micropropagation process was studied. Results showed that sugarcane bagasse the experiments were better than the commercial medium (agar). In the acclimatization step $100 \%$ of survival were obtained, which could manipulate the costs of the total micropropagation process.

\section{RESUMO}

Para a obtenção de mudas (material vegetal) sadias de espécies de café em maior quantidade e em tempo reduzido, utiliza-se a técnica de micropropagação vegetal. Essa técnica é realizada em diferentes etapas, desde o isolamento até o transporte para extra vitro. Cada etapa demanda tempo e gera custos onerosos, sendo ainda necessário otimizar o rendimento. Para melhorar o processo total é essencial que cada etapa colabore com o máximo de rendimento, no menor tempo e com o menor custo possível. Este trabalho teve como focos as etapas de enraizamento e de aclimatização com as seguintes mudanças previstas: o enraizamento destes micro-tecidos propagados em meio de cultura modificado (substituição do meio semi-sólido por bagaço de mandioca e/ou bagaço de cana-de-açúcar) e a sua fácil aclimatização (permanência de curto tempo nas condições de aclimatização e a rápida formação de torrão para facilitar a transferência das mudas). Comparando os resultados obtidos utilizando-se meio alternativo em relação ao meio comercial (contendo Gelrite), observou-se que, no meio contendo mistura de bagaço de mandioca e bagaço de cana-de-açúcar (20:80), o tamanho das raízes foi em média $20,4 \%$ superior, o tamanho da planta foi $10,9 \%$ superior, o número de folhas foi $26 \%$ superior e o número de raízes formadas foi $8 \%$ superior. Em relação à porcentagem de enraizamento, o meio com substrato alternativo apresentou $80 \%$ e o meio comercial apresentou $66,67 \%$ de êxito. Nos testes de aclimatização foi obtida uma sobrevivência de $100 \%$ para os dois tipos de meio, entretanto houve uma pequena diferença em relação aos números de folhas geradas.

\section{REFERENCES}

Boxus, P. H. (1974), The production of strawberry plants by invitro micropropagation. J. Hortic. Sci., (49), 209-210.

Debergh, P. C. and Maene, L. N J. (1981), A scheme for the commercial propagation of ornamental plants by tissue culture. Scientia Hort., (14), 335-345.

George, E. F. (1993), Plant propagation by tissue culture, Part 1 - The Technology, Exegetics Lirnited, pp. 337-356.

IBGE (2003), Disp. in: http://www.ibge.com.br. Access in: 20 jan. 2003.

Mohan, R. (2001), Propagação vegetativa invitro: uso do bagaço de cana-de-açúcar como material suporte alternativo de baixo custo na fase de enraizamento de marubakaido (Malus prunifolia). Tese de Mestrado, Universidade Federal do Paraná, Curitiba, Brasil.

Mohan, R.; Soccol, C.R.; Quoirin, M. and Pandey, A. (2004), Use of Sugarcane Bagasse as an Alternative Low Cost Support Material during the Rooting Stage of Apple Micropropagation. Invitro - Plant, Journal of the Society for invitro Biology. New Mexico State University.

Murashige, T. and Skoog, F. (1962), A revised medium for rapid growth and bioassays with tobacco tissue cultures. Physiologia plantarum, 15, 473-497.

Romberger, J. A. and Tabor, C. A. (1971), The Picea abies shoot apical meristerm in culture. Agar and autoclaving effects, Am. J. Bot., (58), 131-140.

Received: September 29, 2004; Revised: February 25, 2005; Accepted: March 25, 2005. 